\title{
Impact of Information and Communication Technology on Economic Growth and Population Health in Malaysia*
}

\author{
Rafia AFROZ $^{* * *}$, Md. MUHIBBULLAH ${ }^{* * * *}$, Mohammad Niaz MORSHED ${ }^{* * * * *}$ \\ Received: November 16, 2019 Revised: January 23, 2020 Accepted: February 24, 2020.
}

\begin{abstract}
The paper aims to examine the association between information and communication technology (ICT), economic growth and population health based on health production model in Malaysia. This theoretical health production function is represented as follows: where the output is an individual health outcome, and the inputs are determinants of health, such as income, education, health care costs, medical facilities, the environment, and lifestyle. The development of information and communication technologies are represented as of mobile cellular subscriptions (per 100) and fixed telephone subscriptions (100) using time series data from 1993-2017 from the World Bank database. Using the bound testing technique of cointegration, this study finds that ICT affects population health significantly and positively in the long- and short-run. This is because ICT inclusion improves human health and longevity. Whereas, economic growth has no significant impact on the population's health both in the short- and long-run. The findings indicate that a weak global economy affects Malaysia's economic growth and reduces the health expenditure per capita. The results of this study suggest that policymakers must develop policies that improves public health by increasing health literacy, disseminating health information and facilitating medical facilities. This study also suggests that health care systems should to concentrate on digital inclusion.
\end{abstract}

Keywords: ICT, Economic Growth, Response Surface, Cointegration, Malaysia

JEL Classification Code: C22, I15, I18, K32, O14

\section{Introduction}

\footnotetext{
*The authors would like to acknowledge the P-RIGS (funding of "Digital development, Economics Growth. Environmental Sustainability and Population Health in Malaysia: Applying Response Surfaces for the F-test of cointegration model" (Ref no: P-RIGS18-006-006)

${ }^{* *}$ First Author and Corresponding Author. Associate Professor, Department of Economics, Faculty of Economics and Management Sciences, International Islamic University Malaysia, Malaysia[Postal Address: Jalan Gombak, 53100, Selangor, Malaysia]

Tel: +603 61964748, Email: rafia@iium.edu.my

${ }^{* * *} \mathrm{PhD}$ student, Department of Economics, Faculty of Economics and Management Sciences, International Islamic University Malaysia, Malaysia. Email: muhibedu@gmail.com

**** Department of Finance, Faculty of Economics and Management Sciences, International Islamic University Malaysia, Malaysia. Email: tanbirbiu45@gmail.com

(C) Copyright: The Author(s)

This is an Open Access article distributed under the terms of the Creative Commons Attribution Non-Commercial License (http://Creativecommons.org/licenses/by-nc/4.0/) which permits unrestricted noncommercial use, distribution, and reproduction in any medium, provided the original work is properly cited.
}

Malaysia's health care system has achieved remarkable results in improving the health of the population, as demonstrated by a significant reduction in infant mortality by $90 \%$, mortality in children under 5 years by $88 \%$ and maternal mortality by $89 \%$. This has led to a higher survival rate (72.5 years for men and 72.5 years for women). In 2017, life expectancy at birth in Malaysia was 72.7 years for men and 77.4 years for women (Department of Statistics Malaysia, 2017). The infant mortality rate in Malaysia decreased from 6.8\% in 2007 to $6.7 \%$ in 2017 (Statista, 2018). The limited number of health professionals indicates that there will be a problem in the future. For example, it will be assumed that a doctor will treat 1,300 patients. Worse still, the proportion of pharmacists concerning the population of Malaysia is 1: 1,600, which is lower than the ideal rate of 1: 1,200 (The Star Online, 2017). According to the National Immunisation Programme, children are subsidised by the federal government as a global strategy to combat infectious but preventable diseases. This vision is an inspiration for the development of health services and provides the basis for the development and use of medical 
informatics in the provision of medical services. In this article, we explore the relationship between health care and the development of information and communication technologies using data from two intermediate variables taken from the World Bank database. These variables are mobile cellular subscriptions (per 100) and fixed telephone subscriptions (100). The paper attempts to answer the following two questions:

(1) Do ICTs lead to better health outcomes in Malaysia?

(2) Does Malaysia's economic growth affect health?

\section{Literature Review}

Information and communication technologies (ICT) play the most important part in improving public health. There exist several methods in which technology improves health care and other health consequences.It develops access for geologically remote societies, delivers funding to healthcare employees, expands information distribution, and deals graphic apparatuses for gathering information on the people and the atmosphere on recognised illnesses, as well as keeping and handling information. Lucas (2008) evaluates the possible positive effects of ICT invention in emerging countries' well-being schemes. The author determines that ICT solicitations can advance the performance of current health schemes.

Awan, Afzal, Majeed, Waqas, and Gilani (2017) observed that the development of ICT technologies recovers the health of the people by increasing life expectancy and reducing infant mortality. This is due to the fact that the inclusion of ICT leads to good relationships and healthy behavior, thereby improving human health and longevity. West (2015) trusts that the usage of a mobile phone helps studied group of African countries because mobile phone equipment delivers a chance to recover the abilities of doctors and advance the services provided in critical cases for mothers and children in due time. Tsai, Mendenhall, Trostle, and Kawachi (2017) delivered evidence that the e-learning system (BELS), which combines face-to-face classes with e-learning modules, has improved health education for nurses in the hospitals. ColeLewis and Kershaw (2010) deliver a organized evaluation of text messaging by phone as a tool for behavioural change in disease management and hindrance. They note positive signs of weight loss, smoking cessation and diabetes treatment. They argue that text messaging can be an important tool for reducing the global burden of healthcare, providing more effective support for disease prevention and treatment. Déglise, Suggs, and Odermatt (2012) discuss that mobile phones perform as an operational instrument for fighting diseases in developing countries. They contend that mobile phones are a inexpensive method to encounter the particular requirements of health systems and can deliver new chances for good health of people in developing countries.

In contrast to the positive results regarding medical information on the Internet, Kiley (2002) argues that deception can cause redundant nervousness, avoidable illness, or even child death. Secondly, some socioeconomic groups do not have satisfactory entrance to the net. In this case, the Internet may aggravate existing socioeconomic dissimilarities in health status (Awan et al., 2017). Third, health statistics can lead to avoidable appointments by patients who take time from their doctors. In a study conducted in America, 39\% of respondents approved that info on the Internet are the sources for unnecessary visits to doctors (see Murray, Lo, Pollack, Donelan, Catania, White, $\&$ Turner, 2003; Lee, 2017). Likewise, other studies have critiqued the usage of ICT for improving health systems. Bend (2004) found that "given the quantity and extent of projects and valuations that we deliberate, we found a astonishingly minor quantity of conclusive indication that ICTs can pass additional significance to public health".

Real gross domestic product (GDP) per capita, which regulates the average of living, is also reflected one of the well-known causes of public health. O'Hara and McCabe (2013) show that a 10\% growth in average per capita GDP heads to a $10 \%$ reduction in child death if the crucial child mortality rate in the country is 50 per 1000 live births. Medical organisations are additional significant determinant of health (Singh, Singh, Gupta, \& Kumar, 2014; Mohapatra, Palo, \& Mohanty, 2017). If the quantity of doctors is large, admission to medical amenities and facilities will be superior. This will increase the life expectancy of the population. Likewise, if the quantity of children vaccinated compared to measles increases, the number of children dying before their first birthday will decrease (Mohapatra et al., 2017; Awan et al., 2017). Lee and Xuan (2019) suggested that promoting technology and innovation management and supporting $R \& D$ subsidies may reduce the marginal cost of conducting $R \& D$ and increase the rate of technology and innovation management and R\&D activity and therefore, the total factor productivity growth rate.

In recent years, the results of health investigation connected to the overview of ICT structure have been the topic of close thoughtfulness of investigation researchers and politicians. However, theoretical relationships forecast contradictory health effects for ICT systems. Therefore, an empirical assessment of the association among economic growth, health and ICT is necessary for a deeper understanding of the relationship. Since the theoretical association of ICT with health consequences suggests both positive and negative effects, it becomes necesary to determine empirically whether positive or negative effects 
of ICT affect health outcomes and assess whether these effects differ depending on the ICT measures used. To this end, this study examines the association among the growth of ICT technologies, economic growth and the health of the population in Malaysia using small sample data.

\section{Methodology}

A nation's health production function shows the health statistics of the nation. It illustrates the relationship between inputs and outputs for a specific period. According to Grossman (1972), health is created by people according to their behaviour, medical care, and the limitations they face. This theoretical health production function is represented as follows:

\section{$\mathrm{H}=\mathrm{f}($ inputs to health)}

where $\mathrm{H}$ is an individual health outcome, and input is a determinant of health, such as income, education, health care costs, medical facilities, the environment, and lifestyle. This model was developed to study the production function of health at the micro level. To transform this model at the macro level, health care costs are presented in per capita form and reorganised into three categories; social, economic and environmental factors after Fayissa and Gutema (2005).

$$
\mathrm{H}=\mathrm{f}(\mathrm{Y}, \mathrm{S}, \mathrm{V})
$$

where $Y, S$ and V represent vectors of economic, social and environmental variables, respectively. Several variables come under each vector, but each study has used different variables because of reliable and sufficient data availability and other limitations.

In this study, social and environmental factors are excluded from the model. Only economic and ICT factors are included in the model. For our empirical research, the variables in the vector of economic factors here include economic growth and medical institutions, and the variables in ICT factors include subscriptions to mobile cellular networks (by 100) and subscriptions to fixed phones (100). The Internet can facilitate the provision of services, including medical services, to expectant and nursing mothers. Moreover, it can facilitate communication between patients and health systems (Bankole \& Ajila, 2013; Khan \& Majeed, 2018). This can improve the management and efficiency of government, public utilities (such as public transport, water delivery). For this reason, we added ICT to our model.

$$
\mathrm{H}=\mathrm{f}(\text { Economic growth, health facilities, ICT) }
$$

In this analysis, we used real gross domestic product (GDP) as indicators of economic growth, the number of doctors and measles vaccinations as indicators of medical institutions, life expectancy and infant mortality as indicators of health. We expect a positive (negative) growth rate with life expectancy (infant mortality). This study uses a $\log$ of all variables for analysis. Table 1 lists the model variables and data sources. Descriptive statistics of variables are presented in Table 2 .

\begin{tabular}{|c|c|c|}
\hline Data / Variable & Measurement & Sources of data \\
\hline $\begin{array}{l}\text { Real Gross Domestic Product } \\
\text { Per capita (GDP) }\end{array}$ & US\$ & World Bank \\
\hline $\begin{array}{l}\text { Mobile Cellular Subscription } \\
\text { (MOB) }\end{array}$ & Unit & World Bank \\
\hline $\begin{array}{l}\text { Fixed Broadband } \\
\text { Subscription (BB) }\end{array}$ & Unit & World Bank \\
\hline $\begin{array}{l}\text { Immunization, measles } \\
\text { (IMM) }\end{array}$ & $\begin{array}{l}\% \text { of children } \\
\text { ages } 12- \\
23 \text { months }\end{array}$ & World Bank \\
\hline Physicians & (per 1000 people) & World Bank \\
\hline Life expectancy (LIFE) & $\begin{array}{l}\text { life expectancy at } \\
\text { birth, total } \\
\text { (years) }\end{array}$ & World Bank \\
\hline $\begin{array}{l}\text { Infant mortality rate, infant } \\
\text { (MR) }\end{array}$ & $\begin{array}{l}\text { per } 1000 \text { live } \\
\text { births }\end{array}$ & World Bank \\
\hline
\end{tabular}

Table 1: Data and Variables

Table 2: Descriptive statistics

\begin{tabular}{|c|c|c|c|c|c|c|c|}
\hline & InMR & InLIFE & InGDP & InMOB & InBB & InIMM & InPHY \\
\hline Mean & 3.68 & 4.29 & 2.80 & 1.29 & 1.86 & 4.43 & 1.08 \\
\hline Minimum & 0.54 & 4.26 & 2.50 & 1.10 & 1.54 & 3.55 & 0.43 \\
\hline Maximum & 5.01 & 4.33 & 2.98 & 1.45 & 2.08 & 4.58 & 1.81 \\
\hline Standard deviation & 1.38 & 0.01 & 0.12 & 0.12 & 0.18 & 0.236 & 0.41 \\
\hline Observations & 25 & 25 & 25 & 25 & 25 & 25 & 25 \\
\hline
\end{tabular}


The cointegration technique for analysing the relationship between variables is widely used in macroeconomics. Many studies have used the cointegration test based on the F-test for the joint value of the members of the levels in the error correction model. Some studies have tested cointegration between variables using a onemember t-test for error correction. Pesaran, Shin, and Smith (2001) (PSS) approached another cointegration test, without considering the order of integration of variables for large sample data. Narayan (2004) accepted a similar test by developing new critical values for small sample data from 30 to 80. Later, Carreras et al. (2006) expanded the Narayan (2004) approach to improve the cointegration test, introducing response surfaces for the F-test cointegration model. The advantage of this test is that it allows the user to generate critical test values for very small sample data.

This study adopted the F-test of the cointegration method developed by Pesaran et al. (2001). Critical test values were calculated using the surface response method proposed by Carreras et al. (2006). You can test cointegration between variables by checking the joint significance of the level members in the error correction equation by associating two or more variables of interest, as shown below:

$$
\Delta \mathrm{y}_{\mathrm{t}}=\underset{\mathrm{u}_{\mathrm{t}}}{\alpha_{\mathrm{o}}}+\alpha_{1} \Delta \mathrm{x}_{\mathrm{t}}+\alpha_{2} \mathrm{y}_{\mathrm{t}-1}+\sum_{\mathrm{j}=1}^{\mathrm{k}-1} \alpha_{2+1} \mathrm{x}_{\mathrm{jt}-1}+\underset{2+\mathrm{k}}{\mathrm{t}}+
$$

where $\mathrm{k}-1$ is the number of variables in the regression and $t$ is the trend. The null hypothesis of this test is Ho: $\alpha_{2}=$ $\alpha_{3} \ldots \ldots \ldots \ldots=\alpha_{2+\mathrm{k}-1}=0$. The critical values for the cointegration test suggested by Pesaran et al. (2001) show that it is possible to set the bounds for them. The upper bound is determined by the case in which $\mathrm{x}$ variables are all integrated of order one, and there is no cointegrating relationship between them. The lower bound is determined by the case in which $\mathrm{x}$ variables are stationary or $\mathrm{I}(0)$. It is possible to reject the null hypothesis of no cointegration if the test statistics is above the upper bound and it is not possible to reject it if the statistic is below the lower bound. If it lies between the upper and lower bounds, then more information is required before one can either accept or reject the null. PSS provides a range of asymptotic critical values based on Monte Carlo analysis which correspond to different assumptions concerning the underlying data generation process (inclusion or exclusion of the constant and time trend in the model). So, following Pesaran et al. (2001) general model, the error correction version of the ARDL model for health outcome is used in this study. Various econometric approaches have been used for shortrun and long-run estimations such as an approach by Engle and Granger (1987), Johansen and Juselius (1990), Johansen (1996). The ARDL approach has some advantages, as follows: First, the estimations are unbiased and even in the case of small sample size; Second, it can apply in all three cases whether the variables are stationary at $\mathrm{I}(0)$ or stationary at $\mathrm{I}(1)$ even there is a mixture of both. Third, if cointegration confirms among variables, then it is a useful approach for both short-run and long-run dynamics. Fourth, this is the only approach that provides us with some explicit tests through which we can explore that exclusive cointegration exists or not instead of assuming vector existence (Nkoro \& Uko, 2016; Nguyen, \& Ngoc, 2020; Qamruzzaman, Karim, \& Wei, 2019; Le, Duy, \& Ngoc, 2019; Ali \& Fei, 2016). The ARDL model can be specified as:

$$
\begin{aligned}
& \Delta \ln (\mathrm{H})_{\mathrm{t}}=\alpha_{0}+\sum_{\mathrm{i}=1}^{\mathrm{p}} \varphi_{\mathrm{i}} \Delta \ln (\mathrm{H})_{\mathrm{t}-\mathrm{i}}+ \\
& \sum_{\mathrm{i}=0}^{\mathrm{p}} \varphi_{\mathrm{i}} \Delta \ln (\mathrm{Y})_{\mathrm{t}-\mathrm{i}}+\sum_{\mathrm{i}=0}^{\mathrm{p}} \varphi_{\mathrm{i}} \Delta \ln (\mathrm{HF})_{\mathrm{t}-\mathrm{i}}+ \\
& \sum_{\mathrm{i}=0}^{\mathrm{p}} \varphi_{\mathrm{i}} \Delta \ln (\mathrm{ICT})_{\mathrm{t}-1}+\delta_{\mathrm{i}} \ln (\mathrm{H})_{\mathrm{t}-1}+ \\
& \delta_{\mathrm{i}} \ln (\mathrm{Y})_{\mathrm{t}-1}+\delta_{\mathrm{i}} \ln (\mathrm{HF})_{\mathrm{t}-1}+\delta_{\mathrm{i}} \ln (\mathrm{ICT})_{\mathrm{t}-1}+ \\
& \mathrm{v}_{\mathrm{t}}
\end{aligned}
$$

$H$ is health status measured by life expectancy at birth, total (years), and infant mortality per $1000, Y$ is GDP per capita (constant 2005 US\$), HF is health facilities (immunisation measles), and ICT is ICT technologies. We have estimated two models. Furthermore, in model 1, life expectancy at birth is used as the dependent variable, and in model 2 , infant mortality is used as the dependent variable. This study uses physicians supply as one of the independent variables measured by "physicians (per 1000 people)" for model 1 and immunisation as one of the independent variables measured by "Immunisation, measles ( $\%$ of children ages 12-23 months)" for model 2. Also, GDP per capita and ICT variables are used as independent variables in both models. Schwarz Bayesian Criterion (SBC) is used to select the lag length of the model.

As for this present study, the F-test statistics are compared against the critical values which are selfcalculated based on response surface (Carreras et al., 2006) of the form:

$$
C_{i}(p)=\beta_{0}+\frac{\beta_{1}}{T}+\frac{\beta_{2}}{T^{2}}+\varepsilon_{i}
$$

Where $C_{i}(p)$ denotes the $p \%$ quantile estimate for the $i$ th experiment, $\beta$ 's values are based on response surface estimates produced by Carreras et al. (2006), $\mathrm{T}$ is sample size, and $\varepsilon_{\mathrm{t}}$ is a random walk. If there is evidence of longrun relationship (cointegration) of the variables, the long-run model is estimated, and the ARDL specification of the short-run dynamics can be derived.

As for this present study, the F-test statistics are compared against the critical values which are selfcalculated based on response surface ${ }^{9}$ of the form: 


$$
C_{i}(p)=\beta_{0}+\frac{\beta_{1}}{T}+\frac{\beta_{2}}{T^{2}}+\varepsilon_{i}
$$

Where $C_{i}(p)$ denotes the $p \%$ quantile estimate for the $i$ th experiment, $\beta$ 's values are based on response surface estimates produced by Carreras et al. (2006), $\mathrm{T}$ is sample size, and $\varepsilon_{\mathrm{t}}$ is a random walk. If there is evidence of longrun relationship (cointegration) of the variables, the longrun model is estimated, and the ARDL specification of the short-run dynamics can be derived.

Table 3: Unit Root Tests

\begin{tabular}{|c|c|c|c|c|c|}
\hline \multirow{2}{*}{ Variable } & \multicolumn{2}{|c|}{$\begin{array}{l}\text { ADF test statistics } \\
\text { (with trend and intercept) }\end{array}$} & \multicolumn{2}{|c|}{$\begin{array}{c}\text { P-P test statistics } \\
\text { (with trend and intercept) }\end{array}$} & \multirow[t]{2}{*}{ Order of Integartion } \\
\hline & Level & First Difference & Level & First Difference & \\
\hline $\operatorname{lnLIFE}$ & -1.29 & $-3.37 * *$ & -1.05 & $-3.81^{* * *}$ & $\mathrm{I}(1)$ \\
\hline lnMOR & $-3.27^{* *}$ & -1.49 & $-3.30^{* *}$ & -1.02 & $\mathrm{I}(0)$ \\
\hline $\ln \mathrm{PHY}$ & -1.46 & $-3.69^{* * *}$ & -1.46 & $--3.24^{* * *}$ & $\mathrm{I}(1)$ \\
\hline $\operatorname{lnGDP}$ & -1.73 & $-3.18^{* * *}$ & -1.84 & $-3.86^{* * *}$ & $\mathrm{I}(1)$ \\
\hline lnIMM & -1.47 & $-3.19^{* * * *}$ & -1.44 & $-3.05^{* * *}$ & $\mathrm{I}(1)$ \\
\hline $\operatorname{lnFIX}$ & -1.39 & $-4.50^{* * *}$ & -1.70 & $-3.55^{* * *}$ & $\mathrm{I}(1)$ \\
\hline $\operatorname{lnMOB}$ & -1.39 & $-4.53^{* * *}$ & -0.70 & $-4.55^{* * *}$ & $\mathrm{I}(1)$ \\
\hline \multicolumn{6}{|c|}{ Note: $\quad * * *$ significant at $1 \%, * *$ significant at $5 \%, *$ significant at $10 \%$} \\
\hline
\end{tabular}

Table 4: F-statistics for cointegrating relationship in model 1

\begin{tabular}{|c|c|c|c|c|c|}
\hline $\begin{array}{c}\text { F-test } \\
\text { statistics }\end{array}$ & Lag & $\begin{array}{l}\text { Sig. } \\
\text { level }\end{array}$ & $\begin{array}{r}\text { Adjus } \\
\text { (unrest }\end{array}$ & $\begin{array}{l}\text { al Values* } \\
\text { ad no trend) }\end{array}$ & Outcome \\
\hline \multirow{4}{*}{1.82} & \multirow{4}{*}{2} & & $\mathrm{I}(0)$ & $\mathrm{I}(1)$ & \multirow{4}{*}{$\begin{array}{l}\text { There is no } \\
\text { cointegration } \\
\text { (reject } \mathrm{H}_{0} \text { ) }\end{array}$} \\
\hline & & $1 \%$ & 6.328 & 7.993 & \\
\hline & & $5 \%$ & 4.260 & 5.538 & \\
\hline & & $10 \%$ & 3.416 & 4.532 & \\
\hline
\end{tabular}

Note: * Critical values are calculated based on response surface (Carreras et al., 2006)

Table 5: F-statistics for cointegrating relationship in model 2

\begin{tabular}{|c|c|c|c|c|c|}
\hline $\begin{array}{c}\text { F-test } \\
\text { statistics }\end{array}$ & Lag & $\begin{array}{l}\text { Sig. } \\
\text { level }\end{array}$ & $\begin{array}{l}\text { Adju } \\
\text { Val } \\
\text { inte }\end{array}$ & & Outcome \\
\hline \multirow{4}{*}{6.33} & \multirow{4}{*}{2} & & $\mathrm{I}(0)$ & $\mathrm{I}(1)$ & \multirow{4}{*}{$\begin{array}{l}\text { There is cointegration } \\
\text { (Do not reject } \mathrm{H}_{0} \text { ) }\end{array}$} \\
\hline & & $1 \%$ & 6.328 & 7.993 & \\
\hline & & $5 \%$ & 4.260 & 5.538 & \\
\hline & & $10 \%$ & 3.416 & 4.532 & \\
\hline
\end{tabular}

Note: * Critical values are calculated based on response surface (Carreras et al., 2006)

To analyse the long-term interaction between the estimated variables for this study, equation (1) is estimated. Table 4 presents the results of the F-test for cointegration for model 1 . The results of Table 4 show that the calculated F-statistics is 3.81, which is below the upper limit at all levels of significance $1 \%, 5 \%$ and $10 \%$ using levels of

\section{Empirical Results and Discussion}

It is necessary to test the unit root before checking for the presence of integration. Consequently, Enders (1995) proposed to conduct a unit root test to ensure the degree of stationarity using standard tests ADF and PP. The unit root test results are shown in Table 3. The unit root test results presented in Table 3 show that all variables are stationary, either in levels or in terms of the first difference. Thus, the results of Table 3 are consistent with the hypothesis that the variables are integrated first order I (0) and I (1). 
between variables in model 1 . The results presented in Table 5 imply that there is cointegration among the variables in model 2 since the F-statistic is greater than the upper limit of the critical value at $5 \%$ and $10 \%$ significance levels. For further analysis, we mainly focus on model 2, since there is cointegration between variables.

Since long-term relationships are established, we then evaluate equation 2 to get long-term coefficients. Table 6 presents the estimated results. The immunisation variable has a negative and significant relationship with infant mortality since an increase in immunisation of $1 \%$ leads to a decrease in infant mortality of $0.04 \%$. These results are consistent with Kwong, Stukel, Lim, McGeer, Upshur, Johansen, and Svenson (2008) and Majeed and Khan (2019). This explains that if the number of children immunised against measles increases, the number of children dying before their first birthday will decrease. The results for the error correction model (ECM) are presented in Table 7.

The short-term dynamics of the variables indicate that immunisation and mobile phone have a negative and significant effect on infant mortality. The significance and negative sign of the term error correction (ECT) indicate a causal relationship in at least one direction. The delayed error term (ECTt-1) in our result is negative and significant at the $1 \%$ level in both models. A coefficient of -0.76 indicates that any deviation from the long-run equilibrium between variables is adjusted by about $76 \%$ for each period in order to return to the level of long-run equilibrium. In addition, the diagnostic tests in the model do not indicate the presence of serial correlation or heteroscedasticity. To confirm the consistency and effectiveness of the model, a diagnostic test is carried out, and the result is also shown in Table 7. The results of three diagnostic tests of the Lagrange multiplier for sequential correlation, Jacques-Berr for normality and autoregressive conditional heteroscedasticity show that our model has passed all four diagnostic tests, because we cannot reject any hypothesis, and this demonstrates the consistency and effectiveness of our model.

Table 6: Estimated Long Run coefficients based on SBC (dependent variable $=\ln (\mathrm{MOR})$

\begin{tabular}{|c|c|c|}
\hline \multicolumn{3}{|c|}{ Model 3 } \\
\hline Variables & Coefficients & T-ratio (p values) \\
\hline $\ln (\mathrm{GDP})$ & 0.11 & $1.21(0.25)$ \\
\hline $\ln (\mathrm{IMM})$ & -0.04 & $-2.55(0.05)^{* *}$ \\
\hline $\ln (\mathrm{FIX})$ & 0.16 & $1.47(0.17)$ \\
\hline $\ln (\mathrm{MOB})$ & -0.05 & $2.95(0.05)^{* *}$ \\
\hline
\end{tabular}

*** significant at $1 \%$ level, ** significant at $5 \%$ level, * significant at $10 \%$ level
Table 7: Error Correction Regression model (dependent variable= $\mathrm{D}(\operatorname{lnMOR})$

\begin{tabular}{|c|c|c|}
\hline \multirow{2}{*}{ Variables } & \multicolumn{2}{|c|}{ Model 3} \\
\hline & Coefficients & T-ratio (p values) \\
\hline $\mathrm{D}(\operatorname{lnGDP})$ & 0.12 & $1.64(0.15)$ \\
\hline $\mathrm{D}(\mathrm{IMM})_{\mathrm{t}-2}$ & -0.18 & $-2.34(0.05)^{* *}$ \\
\hline $\mathrm{D}(\operatorname{lnFIX})$ & -0.07 & $-0.75(0.48)$ \\
\hline $\mathrm{D}(\operatorname{lnMOB})$ & -0.08 & $-3.92(0.00)^{* * *}$ \\
\hline $\mathrm{ECT}_{\mathrm{t}-1}$ & -0.76 & $-4.17(0.005)^{* * *}$ \\
\hline Adjusted R-square & \multirow{4}{*}{\multicolumn{2}{|c|}{$\begin{array}{c}0.98 \\
38.02 \\
2.56 \\
\\
0.06(0.83) \\
0.054(0.93) \\
0.553(0.82)\end{array}$}} \\
\hline F-statistic & & \\
\hline DW-statistic & & \\
\hline $\begin{array}{c}\text { Diagnostic Test: } \\
\text { Jarque-Bera } \\
\text { Fhet } \\
\text { LM }\end{array}$ & & \\
\hline
\end{tabular}

*** significant at $1 \%$ level, $* * \quad$ significant at $5 \%$ level, * significant at $10 \%$ level

\section{Conclusion and Policy Recommendation}

This study expands the existing literature on the determinants of health, empirically exploring the impact of ICT on public health, using the methodology of joint testing. New test critical values are recalculated to match small sample data based on the response surface proposed by Carreras et al. (2006). Data for several proxy variables of interest are taken for Malaysia for the period 1993-2017. In this study, life expectancy at birth and infant mortality are used as dependent variables. We measured ICT infrastructure using two proxy servers (1) cellular subscribers (per 100), (2) fixed telephone subscribers (per $100)$.

This study confirms that increasing ICT improves people's health in terms of increasing life expectancy and reducing infant mortality. This is due to the fact that digital integration leads to good relationships and healthy behaviour, thereby improving human health and longevity. In addition, immunisation significantly reduces infant mortality. On the other hand, GDP does not have a significant impact on public health. This study is limited to two indicators of health effects, which include life expectancy and infant mortality. In future studies, various health indicators may be used, such as maternal health, mental health and various diseases. 


\section{References}

Ali, M. A., \& Fei, Y. S. (2016). Impact of Malaysia's capital market and determinants on economic growth. Journal of Asian Finance, Economics and Business, 3(2), 5-11. https://doi.org/10.13106/jafeb.2016.vol3.no2.5.

Awan, M., Afzal, M., Majeed, I., Waqas, A., \& Gilani, S. A. (2017). Assessment of knowledge, attitude and practices regarding occupational hazards among Nurses at Nawaz Sharif Social Security Hospital Lahore Pakistan. Saudi Journal of Medical and Pharmaceutical Scinces, 3(6), 622-630. Available at: http://scholarsmepub.com/sjmps-36/

Bankole, A. A., \& Ajila, S. A. (2013, March). Cloud client prediction models for cloud resource provisioning in a multitier web application environment. Paper presented at the 2013 IEEE Seventh International Symposium on ServiceOriented System Engineering (pp. 156-161), San Francisco, California. DOI: 10.1109/SOSE.2013.40

Bend, J. (2004). Public value and e-health. London, UK: Institute for Public Policy Research (IPPR).

Carreras, C., Pont, S., Maffucci, F., Pascual, M., Barcelo, A., Bentivegna, F., \& Aguilar, A. (2006). Genetic structuring of immature loggerhead sea turtles (Caretta caretta) in the Mediterranean Sea reflects water circulation patterns. Marine Biology, 149(5), 1269-1279.

Carreras, P. E., Turner, S. E., \& Wilkinson, G. T. (2006). Tahiti: development strategy assessment using design of experiments and response surface methods. Paper presented at SPE Western Regional/AAPG Pacific Section/GSA Cordilleran Section Joint Meeting, Anchorage, Alaska.

Cole-Lewis, H., \& Kershaw, T. (2010). Text messaging as a tool for behavior change in disease prevention and management. Epidemiologic Reviews, 32(1), 56-69.

Déglise, C., Suggs, L. S., \& Odermatt, P. (2012). SMS for disease control in developing countries: a systematic review of mobile health applications. Journal of Telemedicine \& Telecare, 18(5), 273-281.

Department of Statistics Malaysia. (2017). Abridged life tables, Malaysia, 2015-2017. Retrieved January 24, 2019, from https://www.dosm.gov.my/v1/index.php?r=column/pdfPrev\&i $\mathrm{d}=\mathrm{dkdvKzZ0K1NiemEwN1JteDBSUGorQT09}$

Enders, W. (1995). Applied Econometric Time Series. Hoboken, NJ: John Wiley \& Sons.

Fayissa, B., \& Gutema, P. (2005). Estimating a health production function for Sub-Saharan Africa (SSA). Applied Economics, 37(2), 155-164.

Grossman, M. (1972). On the concept of health capital and the demand for health. Journal of Political Economy, 80(2), 223255.

Islam, M. Z., Ahmed, Z., Saifullah, M. K., Huda, S. N., \& AlIslam, S. M. (2017). CO2 Emission, Energy Consumption and Economic Development: A Case of Bangladesh. Journal of Asian Finance, Economics and Business, 4(4), 61-66. http://dx.doi.org/10.13106/jafeb.2017.vol4.no4.61

Khan, F. N., \& Majeed, M. T. (2018). Education levels and life expectancy of males and females: Empirical evidence from Pakistan. Munich Personal RePEc Archive, Munich University Library, Germany.

Kiley, R. (2002). Does the internet harm health? Some evidence exists that the internet does harm health. British Medical Journal, 324(7331), 238-239. Available at: https://europepmc.org/articles/pmc1122149

Kwong, J. C., Stukel, T. A., Lim, J., McGeer, A. J., Upshur, R. E., Johansen, H., \& Svenson, L. W. (2008). The effect of universal influenza immunization on mortality and health care use. PLoS Medicine, 5(10), e211. https://doi.org/10.1371/journal.pmed.0050211

Lucas, H. (2008). Information and communications technology for future health systems in developing countries. Social Science \& Medicine, 66(10), 2122-2132.

Le, N. H., Duy, L. V. Q., \& Ngoc, B. H. (2019). Effects of Foreign Direct Investment and Human Capital on Labour Productivity: Evidence from Vietnam. Journal of Asian Finance, Economics and Business, 6(3), 123-130.

https://doi.org/10.13106/jafeb.2019.vol6.no3.123

Lee, J. W. (2017). Critical factors affecting consumer acceptance of online health communication: an application of service quality models. Journal of Asian Finance, Economics and Business, 4(3), 85-94.

http://dx.doi.org/10.13106/jafeb.2017.vol4.no3.85

Lee, J. W., \& Xuan, Y. (2019). Effects of Technology and Innovation anagement and Total Factor Productivity on the Economic Growth of China. Journal of Asian Finance, Economics and Business, 6(2), 63-73. https://doi.org/10.13106/jafeb.2019.vol6.no2.63

Majeed, M. T., \& Khan, F. N. (2019). Do information and communication technologies (ICTs) contribute to health outcomes? An empirical analysis. Quality \& Quantity, 53(1), 183-206.

Mohapatra, S. K., Palo, H. K., \& Mohanty, M. N. (2017). Detection of Arrhythmia using Neural Network. Annals of Computer Science and Information Systems, 14, 97-100.

Murray, E., Lo, B., Pollack, L., Donelan, K., Catania, J., White, M.,\& Turner, R. (2003). The impact of health information on the internet on the physician-patient relationship: patient perceptions. Archives of Internal Medicine, 163(14), 17271734.

Narayan, P. (2004). Reformulating critical values for the bounds F-statistics approach to cointegration: an application to the tourism demand model for Fiji. Clayton, Australia: Monash University. Retrieved from https://trove.nla.gov.au/work/3795448

Nguyen, H. M., \& Ngoc, B. H. (2020). Energy ConsumptionEconomic Growth Nexus in Vietnam: An ARDL Approach with a Structural Break. Journal of Asian Finance, Economics and Business, 7(1), 101-110.

https://doi.org/10.13106/jafeb.2020.vol7.no1.101

O'hara, M. W., \& McCabe, J. E. (2013). Postpartum depression: current status and future directions. Annual Review of Clinical Psychology, 9, 379-407.

Pesaran, M., Shin, Y., \& Smith, R. (2001). Bounds testing approaches to the analysis of level relationships. Journal of Applied Econometrics, 16(3), 289-326.

Qamruzzaman, M., Karim, S., \& Wei, J. (2019). Does Asymmetric Relation Exist between Exchange Rate and Foreign Direct Investment in Bangladesh? Evidence from Nonlinear ARDL Analysis. Journal of Asian Finance, Economics and Business, 6(4), 115-128. 
https://doi.org/10.13106/jafeb.2019.vol6.no4.115

Singh, R., Singh, H. K., Gupta, S. C., \& Kumar, Y. (2014). Pattern, severity and circumtances of injuries sustained in road traffic accidents: a tertiary care hospital-based study. Indian Journal of Community Medicine, 39(1), 30-34.

STATISTA. (2018). Malaysia: Infant mortality rate from 2007 to 2017 (in deaths per 1,000 live births). Retrieved November 21, 2018, from https://www.statista.com/statistics/807002/infantmortality-in-malaysia/

The Star Online. (2017, September 24). Country still needs more pharmacists. Retrieved September 25, 2018, from https://www.thestar.com.my/news/nation/2017/09/24/countrystill-needs-more-pharmacists-ministry-our-current-ratio-isless-than-ideal\#36jVExH3DoqHPoYg.99

Tsai, A. C., Mendenhall, E., Trostle, J. A., \& Kawachi, I. (2017). Co-occurring epidemics, syndemics, and population health. The Lancet, 389(10072), 978-982.

West, D. M. (2015). Using mobile technology to improve maternal health and fight Ebola: A case study of mobile innovation in Nigeria. Center for Technological Innovation at Brookings, 19, 308-312. 